\author{
Marta Kaźmierczak \\ Uniwersytet Warszawski \\ mkazmierczak@uw.edu.pl
}

\title{
TŁUMACZ I SKOPOS W FILHARMONII
}

DOI: http://dx.doi.org/10.12775/RP.2017.010

\begin{abstract}
Zarys treści: Przedmiotem artykułu jest obecność tłumaczy w filharmonii na przykładzie działalności Filharmonii Łódzkiej w sezonach 2013/2014-2015/2016. Autorka bada, co się dla FŁ przekłada, w jaki sposób oraz czy podmiotowość tłumacza jest szanowana. Jako szczególny przypadek rozpatruje zaprezentowane w roku 2015 tłumaczenie Vier letzte Lieder Richarda Straussa (teksty: Herman Hesse, Joseph von Eichendorff), z uwzględnieniem aspektów estetycznych, językowych, melicznych. Omówienie ma na celu zbadanie funkcjonalności przekładu w odniesieniu do założonych odbiorców (tekst udostępniany słuchaczom) - stąd ulokowanie analizy w paradygmacie skoposu.
\end{abstract}

Słowa kluczowe: przekład, muzyka, filharmonia, funkcjonalność przekładu, widzialność tłumacza, Richard Strauss

M uzykę uznaje się za język uniwersalny, za sposób komunikacji artystycznej dostępny każdemu (słyszącemu), w niewielkim stopniu podległy barierom kulturowym. Jak to jednak ujął Bernard Shaw, „though music be a universal language, it is spoken with all sorts of accents" (1932: 91) wprawdzie jest on uniwersalny, ale językiem tym mówi się w różny sposób. Dlatego tłumaczenie może być potrzebne także w instytucji takiej jak filharmonia, co chciałabym zilustrować na przykładzie działalności (publikacyjnej) Filharmonii Łódzkiej (FŁ) w ostatnich kilku sezonach. Jeśli nie obecność tłumacza, to w każdym razie działalność tłumaczeniowa bywa niezbędna na próbach z udziałem zagranicznego dyrygenta czy solisty, chociaż to zjawisko wykracza poza obszar moich rozważań. Fizyczny ślad pracy translatorskiej odnajdujemy jednak w obcojęzycznych materiałach promujących repertuar i orkiestrę. Natomiast meloman przebywający we własnym kraju konfrontuje 
się z przekładem (lub z jego brakiem) najczęściej przy słuchaniu utworów wokalno-instrumentalnych czy oratoryjnych napisanych do tekstu w innym języku (ewentualnie do tekstu będącego tłumaczeniem) - i tego rodzaju materiał w największym stopniu stanowi przedmiot artykułu.

W interesującym nas kontekście instytucjonalnym przekłady zwykle mają łatwo identyfikowalnego inicjatora (por. Nord 2009: 182) - filharmonię - oraz wyraźnie zdefiniowany cel: umożliwienie komunikacji między współtwórcami artystycznej interpretacji dzieła, zachęcenie do skorzystania z oferty koncertowej (typowy tekst operacyjny, por. Reiss [1971] 2000: 163), przekazanie słuchaczom treści pojęciowej wykonywanego utworu (oferta informacji - por. Vermeer 1986: 33). Dlatego wydaje się zasadne rozpatrywać ich kształt i funkcjonowanie w ramach teorii skoposu (Vermeer [1989] 2000, por. Schäffner 1998). Także przekład utworów melicznych (dwusemiotycznych) bywa często analizowany w kategoriach funkcjonalnych (przez badaczy takich jak Johan Franzon, Peter Low i Klaus Kaindl; popularność tej perspektywy podkreśla Şebnem Susam-Sarajeva, 2008: 191). Funkcjonalizm może zatem stanowić wspólną ramę dla rozpatrywania różnych gatunkowo tekstów, które składają się na materiał badawczy. Kompozycja korpusu odzwierciedla ewolucję rozwiązań edycyjnych stosowanych przez FŁ:

- programy miesięczne FŁ 2011/2012 - 2015/2016,

- ARPO monthly fliers 2011/2012 - 2013/2014 - ich angielskie odpowiedniki,

- „Kwarta” (czasopismo koncertowe FŁ) - rocznik 2012/2013 (ostatni),

- programy koncertowe FŁ 2013/2014 - 2015/2016.

Celem studium jest zbadanie, jakie teksty podlegają translacji, w jakiej formie, jaka jest jakość tłumaczeń. Ma to umożliwić zarysowanie profilu filharmonii jako zleceniodawcy oraz - ponieważ funkcja konstytuuje się w akcie odbioru (por. Nord 2009: 176) - ustalenie, w jakim stopniu strategia ta odpowiada potrzebom słuchaczy.

\section{Co podlega tłumaczeniu?}

Nie wszystkie teksty (tekst rozumiem tu szeroko), które potencjalnie mogłyby zaistnieć $\mathrm{w}$ tłumaczeniu, podlegają przekładowi. Warto zatem zacząć od omówienia tego, co dla filharmonii się tłumaczy, kiedy i w jakich okolicznościach.

Po pierwsze, tłumaczenie odbywa się $\mathrm{w}$ dwóch kierunkach: $\mathrm{z}$ polskiego i na polski, co rozgranicza kryterium typu tekstu. Przekłady materiałów 
repertuarowych i informacyjnych na język angielski służą rozszerzeniu grupy odbiorców. Nie ma zwyczaju tłumaczenia zapowiedzi koncertowych ani poprzedzających niektóre wydarzenia spotkań z krytykami muzycznymi; nie tłumaczono też programów ani czasopism programowych - decydują tu niewątpliwie względy pragmatyczne. Natomiast przez przynajmniej pięć sezonów (2009-2015) FŁ wydawała programy koncertów równolegle w języku polskim i angielskim. Chodzi o programy miesięczne (monthly fliers), zawierające nie tylko wyszczególnienie pozycji repertuarowych (tu pracę można by uznać za redakcyjną), ale także kilka - zwykle sześć - miniesejów przybliżających proponowane utwory i koncepcję koncertów. Odstąpienie od wydawania wersji angielskiej w ostatnim czasie można tłumaczyć przyczynami ekonomicznymi oraz uznaniem faktu, że obcokrajowcy stanowią mimo wszystko niewielki segment audytorium Filharmonii Łódzkiej. Niewykluczone też, że wiąże się to $\mathrm{z}$ jakimiś zmianami kadrowymi w biurze promocji.

Głównie zajmą nas jednak przekłady dokonywane w drugim kierunku, tzn. polskie warianty tekstów wykonywanych wokalnie w innym języku. Dostępność tłumaczenia jest istotną kwestią, bowiem nawet jeśli prymat przyznany jest kodowi muzycznemu, to możliwość zsemantyzowania tekstu wywiera wpływ na percepcję muzyki. Prezentując utwór z obcojęzycznym tekstem słownym, Filharmonia Łódzka postępuje różnie:

- udostępnia odbiorcom dwujęzyczny tekst utworu;

- udostępnia w druku tylko tekst tłumaczenia;

- odstępuje od zapewniania tłumaczenia.

Zbadany przeze mnie materiał nie wskazuje na regularności pod żadnym względem - tendencje nie zmieniają się w czasie i w niewielkim stopniu zależą od języka oryginału. Jeśli można mówić o uprzywilejowaniu któregoś, byłby nim niemiecki, gdzie nie odnotowałam przypadku niezapewnienia przekładu przy relatywnie wysokiej częstości wykonywania utworów wokalnych i oratoryjnych w tym języku. Porównajmy:

- niemiecki - tłumaczonych 5 z 5,

- łaciński ${ }^{1}$ - tłumaczone 5 z 8 (w jednym wypadku - zmiana strategii),

- francuski - tłumaczony 1 z 2 ,

- rosyjski - tłumaczony 1 (jedyny wykonywany)2.

${ }^{1}$ Do tej grupy zaliczam Carmina burana, choć w skład cyklu wchodzą także teksty łacińsko-niemieckie i napisane w hochdeutsch. Rozmiary korpusu wynikają ze zdecydowanej przewagi utworów symfonicznych w repertuarze FŁ.

${ }^{2}$ Dopisek z sierpnia 2017 roku: w programie koncertu kończącego sezon 2016/2017 pojawiły się arie w języku włoskim, niereprezentowanym we wcześniejszym korpusie. Odnotujmy, że nie były tłumaczone, nie prezentowano także ich oryginalnego tekstu. 
Tendencja do zapewniania tekstów polskich przeważa, trudno natomiast znaleźć motywację dla przypadków, gdy tego zaniechano. Czy czynnikiem decydującym o rezygnacji z tłumaczeń bywa stopień standaryzacji tekstu? Niedrukowanie przekładu dla Mszy nelsońskiej Haydna (FŁ 2012/2013a: 36) tłumaczyłoby się faktem, że tekst łaciński to w tym wypadku tzw. ordinarium, stałe części mszy, z którymi którymi melomani są zaznajomieni. Jednak w ostatnim omawianym sezonie przy wykonaniu Mszy h-moll J.S. Bacha do programu dodano dwujęzyczny druk ulotny z jej tekstem (FŁ 2015/2016d). Dla kontrastu, druku ani przekładu nie doczekał się mniej stypizowany tekst Oratorium na Boże Narodzenie Saint-Saënsa (2015/2016c).

Jak się wydaje, decyzje co do strategii są podejmowane w odniesieniu do konkretnych utworów, w określonych okolicznościach. Na przykład w 2012 roku w czasie jednego koncertu wykonano Trzy psalmy na tenor, chór i orkiestrę Aleksandra Tansmana oraz jego oratorium Prorok Izajasz, oba w języku francuskim; w „Kwarcie” wydrukowano dla słuchaczy tekst psalmów (tylko po polsku), ale nie oratorium - być może zadecydowała objętość tekstu (FE 2012/2013b). Z kolei Carmina burana opatrzono tłumaczeniem dopiero przy drugim (w rozpatrywanym okresie) ich wykonaniu. Trudno spekulować dlaczego, tym bardziej że to w sezonie 2013/2014 publikowano solidniejsze książeczki programowe, w których potencjalnie było miejsce na teksty utworów. $\mathrm{Z}$ pewnością przyczyna nie leżała $w$ nieświadomości istnienia polskiej wersji poematu, w programie towarzyszącym wcześniejszemu wykonaniu podano bowiem dwujęzyczne tytuły utworów cyklu (FŁ 2013/2014c: 1-2), z wykorzystaniem incipitów pochodzących z przekładu przytoczonego w całości dwa lata później (FŁ 2015/2016f).

Obserwujemy różne traktowanie różnych języków wyjściowych w przypadku wydrukowania przekładu. Teksty niemieckie są nieodmiennie przywoływane zarówno w oryginale, jak i w przekładzie (z wyjątkiem oratorium Mendelssohna Eliasz, przy którym wyświetlano napisy). Gdy w repertuarze pojawił się utwór wokalno-instrumentalny $\mathrm{z}$ tekstem $\mathrm{w}$ języku rosyjskim, kantata Prokofiewa Aleksander Newski, w programie znalazł się tylko tekst tłumaczenia (chociaż na końcu odnotowano nazwisko autora rosyjskiego libretta przed nazwiskiem tłumacza - FŁ 2014/2015c). Przyczyn można upatrywać w różnicy alfabetów i/lub niechęci do zastosowania transkrypcji. W sezonie 2015/16 podobną strategię obserwujemy jednak w odniesieniu do łaciny, która zabrzmiała (obok polskiego) w trakcie koncertu pasyjnego: dodatek do programu zawierał tylko teksty polskie, niepowiązane nawet $\mathrm{z}$ tytułami czy incipitami w języku oryginału, co - wolno przypuścić - utrudniało śledzenie przebiegu tekstu kolejnych utworów. Na przykład połączenie tytułu „hymn 
z Officium na okres pasyjny” (incipit „Chorągiew Króla powiewa”) z oryginalnym incipitem Vexilla Regis prodeunt, który zabrzmiał ze sceny, musiało być dla wielu odbiorców rzeczą nieoczywistą. W tym wypadku odstąpienie od przedrukowania oryginału trudniej objaśnić jego „nieprzystępnością”. Niemniej należy zaznaczyć, że kształt językowy niektórych materiałów może zależeć od goszczących solistów i zespołów. Tak zapewne było z dodatkiem tekstowym do programu koncertu pasyjnego przygotowanego przez Schola Gregoriana Silesiensis, gdzie artykuł programowy sygnował Robert Pożarski (FŁ 2015/2016e).

\section{Kto tłumaczy? (Nie)widzialność tłumacza}

Następne pytanie, które warto postawić, dotyczy tego, kto tłumaczy i czy odbiorcy są o tym informowani. Jak wspomniałam, FŁ przez kilka sezonów wydawała materiały promocyjne równolegle w języku angielskim. Autorzy tych rzetelnych i profesjonalnie wykonanych przekładów (świadczących o odpowiednich kompetencjach językowych i dziedzinowych) pozostawali anonimowi. Okoliczności tej niepodobna jednak zinterpretować jako wyrazu szczególnego upodrzędnienia tłumacza, ponieważ programy - także ich polskie warianty - nie zawierają nawet nazwisk autorów tekstów (za to w obu wersjach językowych skrzętnie wymieniało się i wymienia odpowiedzialnych za oprawę graficzną i skład).

$\mathrm{O}$ „unieważnianiu” czy ignorowaniu tłumaczenia świadczą jednak inne fakty, takie jak traktowanie z niedostatecznym pietyzmem autorów przekładów poetyckich i melicznych, a także rozmycie pojęć związanych z przekładem w dyskursie towarzyszącym muzyce.

Szczególna sytuacja zaistniała podczas koncertu z muzyką programową do Hamleta. Wykonaniu utworów Czajkowskiego i Szostakowicza towarzyszyły obszerne fragmenty dramatu Szekspira w interpretacji aktorskiej, lecz tożsamość autora wykorzystanego przekładu nie została podana ani przez recytatora, ani w zapowiedzi koncertowej, ani w programie (FŁ 2013/2014a). Słuchacze - a w tym wypadku mogło to zastanowić znaczny segment widowni - byli zdani na własną pamięć lub domysły w kwestii autorstwa tłumaczenia.

W tym samym sezonie osobliwą niekonsekwencję znajdujemy przy prezentacji recitalu, w którego programie znalazły się m.in. następujące pieśni: 


\section{Jan Gall}

Dziewcze z buzia jak malina op. $1 \mathrm{nr}$ 3, słowa: Heinrich Heine, tłumaczenie Stanisław Rossowski [...]

\section{Michaił Glinka}

Serce podbiłaś mi, dziewczyno

słowa: Aleksander Puszkin [...]

Jean-Paul-Égide Martini

Plaisir d'amour, słowa: Jean-Pierre Claris de Florian

(przekład Wisława Szymborska) (FŁ 2013/2014b: 2-3)

W przypadku utworu polskiego skomponowanego do tłumaczenia zidentyfikowano tłumacza (najwyraźniej zresztą mylnie: ten przekład Mädchen mit dem roten Mündchen wykonał Marian Gawalewicz ${ }^{3}$, zob. druki muzyczne: Gall 1892, Marek 1953: 38-39). Przy kompozycji rosyjskiej brak wzmianki o tłumaczu, a jednak ma ona zabrzmieć po polsku. Natomiast w przypadku pieśni francuskiej zapis podsuwa sprzeczne sugestie: tytuł podano po francusku, a równocześnie zaznaczono fakt przekładu.

Podobne zagadki stawiały przed odbiorcą nie tylko programy. Zamieszczony w czasopiśmie koncertowym „Kwarta” (które pełniło we wcześniejszych sezonach rolę zbiorczego programu dwumiesięcznego) artykuł Witolda Paprockiego poświęcony formie concerto grosso kończy się przywołaniem tekstu wierszy - zapewne samego Vivaldiego - które kompozytor dołączył do Czterech pór roku, by podkreślić programowy charakter muzyki. Pod polskimi tekstami Wiosny, Lata, Jesieni i Zimy znajduje się enigmatyczny dopisek: „Opracowanie na podstawie oryginalnych sonetów i tłumaczeń Witold Paprocki” (Paprocki 2012: 42). Być może tym razem należy przypisać niewidzialność tłumacza (por. Venuti 1995) nie polityce filharmonii, a indywidualnym tendencjom piszącego, gdyż inny tekst tego autora otwiera motto (Paprocki 2013: 66) podpisane nazwiskiem poety - Rilkego - ale nie tłumacza (tym pominiętym jest Artur Sandauer).

Zwróćmy uwage jeszcze na jeden fakt językowy. W programie do Eliasza Mendelssohna znalazła się informacja: „Tekst oratorium będzie wyświetlany na ekranie" (FŁ 2015/2016a). Znamienne, że nie tylko nie wskazano tu autora nadpisów, ale wręcz nie użyto słowa „tłumaczenie”; zwrot „tekst oratorium” w zasadzie należałoby rozumieć jako tekst oryginału, zatem takie sformułowanie dobitnie wskazuje na to, że przekład ma go reprezentować i zastępo-

${ }^{3}$ Rossowski był natomiast autorem słów do innych wczesnych pieśni Galla, jak Piosneczka z ogródka, op. 10. 
wać. Skądinąd w tym wypadku istnieją autoryzowane wersje w dwóch językach - niemieckie libretto złożone z tekstów biblijnych oraz wykonywany już rok po wiedeńskiej premierze przekład angielski Williama Bartholomew (Todd b.d.). W FŁ oratorium zabrzmiało w języku niemieckim, lecz z programu nie wynika jasno, czy nadpisy powstały w oparciu o ten wariant językowy.

Przyjrzyjmy się jednak przede wszystkim temu, jak traktowani są tłumacze wykonywanych w FŁ kompozycji wokalnych. Dość liczne utwory oratoryjne mają libretta oparte na tekście biblijnym, wobec czego nie dziwi, że redaktorzy programów ograniczają się do sygnalizowania, na jakim wydaniu oparty jest tekst polski. Samo dopasowanie tekstu ma tu charakter pracy redakcyjnej, a nie translatorskiej, stąd m.in. podanie tekstu Trzech Psalmów na tenor, chór i orkiestrę Aleksandra Tansmana według Biblii Tysiąclecia (FE 2012/2013b: 18). Analogicznej informacji o źródle polskiego wariantu zabrakło jednak w poprzednim numerze „Kwarty” w odniesieniu do Locus inestimabilis Krzysztofa Grzeszczaka (FŁ 2012/2013a: 36).

Z kolei libretto Passio et mors Domini Nostri Pendereckiego łączy teksty biblijne $\mathrm{z}$ innymi, np. brewiarzowymi. Mimo to jego tłumaczenie opatrzono tylko standardowym odsyłaczem do Biblii (FŁ 2012/2013c: 57), tym samym pomijając m.in. źródło i autora polskich słów hymnu Vexilla Regis prodeunt, nazwanego tu (FŁ 2012/2013c: 52) „Sztandary Króla się wznoszą” (zatem inaczej niż w FŁ 2015/2016e, por. wyżej). Również w Johannespassion Bacha oprócz tekstów ewangelicznych znajdują się różne fragmenty poezji religijnej. W tym wypadku program kończy się adnotacją „Przekład fragmentów Ewangelii: według Biblii Tysiąclecia. Przekład fragmentów pozaewangelicznych: Izabella Szelińska" (FŁ 2013/2014d: 26). Podano nazwiska tłumaczy także w przypadku Pasji według św. Mateusza (FŁ 2014/2015b) oraz wspomnianej kantaty Prokofiewa (FŁ 2014/15c).

Jednak taka identyfikacja, jak już sygnalizowałam, nie zawsze ma miejsce. Co więcej, na niewidzialność skazywani są autorzy tłumaczeń o charakterze wyraźnie literackim. Gdy w przypadku oratorium Josepha Haydna Stworzenie świata Hob.XXI:2 włączono do programu dwujęzyczny tekst libretta - tłumacz (podobnie zresztą jak autor libretta, a jest nim, uzupełnijmy, Gottfried van Swieten) pozostaje anonimowy. Jest to tym bardziej zaskakujące, że mamy do czynienia z przekładem - przynajmniej miejscami - o ambicjach poetyckich, o czym świadczy m.in. finałowa partia chóralna: 
Singt dem Herren alle Stimmen!

Dankt ihm alle seine Werke!

Lasst zu Ehren seines Namens

Lob im Wettgesang erschallen!

Des Herren Ruhm, er bleibt in Ewigkeit!

Amen! Amen!
Cała ziemia rozśpiewana

Niechaj Bogu korne dzięki składa.

Głosząc cześć Imienia Pana,

Niech o cudach opowiada!

Więc chwała $\mathrm{Mu}$, więc chwała $\mathrm{Mu}$,

Na wieczny czas, wieczny czas!

Amen! Amen! (FŁ 2014/2015a: nr 31)

Sposób przekładu partii chóru często wskazuje wręcz na to, że przekład mógł być pierwotnie przeznaczony do wykonywania wokalnego, co tym bardziej domaga się wskazania nazwiska kompetentnego twórcy:

Die Himmel erzählen die Ehre Gottes, Und seiner Hände Werk

Zeigt an das Firmament.

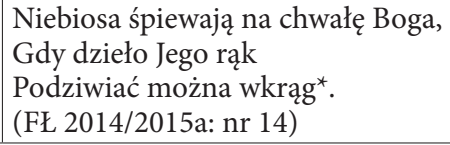

Dramatyczny przykład niewidzialności tłumacza-poety miał miejsce przy wykonaniu kantaty Carla Orffa Carmina burana w czerwcu 2016 roku. Nawet pobieżna lektura ulotki z librettem $\mathrm{w}$ języku polskim ujawnia, że to znacznej próby przekład literacki, nie został on jednak opatrzony nie tylko notą bibliograficzną, ale choćby nazwiskiem tłumacza. Jest to tekst Mariana Piechala (Carmina 1988); jak można wnioskować na podstawie zbieżności błędów w druku (m.in. w cz. 5: „wioną” zamiast „wiosną”, brak przecinka przed „że"), filharmonijni redaktorzy skopiowali go z wersji dostępnej w Internecie (Carmina b.d.), pomijając jednak podane tam nazwisko twórcy. Oczywiście wykorzystanie istniejącego profesjonalnego tłumaczenia zamiast zamawiania pośpiesznie wykonanej wersji filologicznej jest jak najbardziej zasadne, lecz zanegowanie roli jego autora - nieetyczne.

Podsumowując, tłumacz na usługach F€ często pozostaje anonimowy. Kim jest - zawodowym tłumaczem, wykwalifikowanym filologiem, literatem, amatorem? - zwykle nie sposób dociec, nawet jeśli wyjątkowo znamy jego nazwisko. Co więcej, nawet autorstwo uznanych i opublikowanych przekładów nie chroni przed niewidzialnością.

\section{Jak się przekłada?}

Następne pytanie, jakie należy postawić, dotyczy metody tłumaczenia i formy językowej, jaką przybiera translat. W ogromnej większości przypadków są

\footnotetext{
* Pisownia według źródła; tekst nie ma paginacji, dlatego przytaczam numery części.
} 
to w Filharmonii Łódzkiej przekłady, których cel nadrzędny stanowi przekazanie treści warstwy wokalnej utworu. Wprawdzie teoretycy i praktycy tłumaczenia melicznego podkreślają nierozłączność formy i treści utworów dwukodowych (Zagórski 1975; Barańczak 2004), niemniej podejście zarówno dyrektorów filharmonii na świecie, jak i słuchaczy jest pragmatyczne i ma mocną tradycję: w salach koncertowych dominują przekłady filologiczne, bowiem słuchacz śledzi przebieg tekstu oryginalnego powiązanego z muzyką w sensie estetycznym, natomiast dzięki tekstowi we własnym języku zapoznaje się $\mathrm{z}$ jego semantyką. Tak też jest $\mathrm{w}$ badanym korpusie: korzysta się z gotowych tekstów biblijnych i liturgicznych, zapewnia doraźne przekłady filologiczne, przekład meliczny obecny jest śladowo.

Ramy artykułu nie pozwalają na przyjrzenie się większej liczbie tłumaczeń. Wybrałam takie, które reprezentuje uprzywilejowany w repertuarze FŁ język niemiecki, a zarazem wyróżnia się pod względem formalnym oraz poprzez wyeksponowanie osoby tłumaczki. Chodzi o przekład towarzyszący wykonaniu Vier letzte Lieder Richarda Straussa w 2015 roku. W dołączonej do programu ulotce zamieszczono teksty pieśni: Frühling, September, Beim Schlafengehen (sł. H. Hesse) oraz Im Abendrot (sł. J. von Eichendorff) i równolegle ich tłumaczenia - Wiosna, Wrzesien, Zasypiając i O zmierzchu - każde sygnowane nazwiskiem Magdaleny Bartnikowskiej (Strauss [2015]).

\section{Aspekty estetyczne przekładu}

Cztery ostatnie pieśni to niewątpliwie dzieło wybitne. „W niewielu partyturach spełnił się w XX wieku tak doskonale postulat piękna" (Krause 1983: 271), ale na wartość utworu wpływa także niezaprzeczalna harmonia między muzyką a warstwą słowną. Wprawdzie, jak zauważa monografista kompozytora, Ernst Krause, Strauss dobierał teksty do swych pieśni z niewystarczającym niekiedy krytycyzmem (1983: 261), jednak zarzutu miałkości tekstu z pewnością nie można odnieść do Vier letzte Lieder - w tym przypadku mamy do czynienia z liryką Hermanna Hessego i Josepha von Eichendorffa.

W teorii skoposu kluczowym kryterium „fortunnej realizacji” tłumaczenia jest zorientowanie na cel istotny z punktu widzenia odbiorcy (Nord 2009: 176). W przypadku zaś przekładu towarzyszącego wykonaniu wokalnemu w innym języku potrzeby słuchacza wolno zdefiniować jako poznanie treści pojęciowej tekstu, do czego wystarcza przekład filologiczny dostosowany do wymogów idiomatyki. Cztery ostatnie pieśni w rozpatrywanym przekładzie to jednak tekst inny - ambicją tłumaczki było stworzenie przekładu poetyckiego, odzwierciedlającego budowę stroficzną, rymy: 
Lange noch bei den Rosen bleibt er stehn, stehnt sich nach Ruh. Langsam tut er die [großen] müdgewordn’n Augen zu.
Długo jeszcze przy różach Stoi, tęskniąc za spokojem. Później powoli mruży Wielkie, znużone oczy swoje. (2. September / Wrzesień) ${ }^{\star}$

Jeśli celem przekładu miałoby być powstanie wersji artystycznej, należałoby przyjąć założenie, jakie $\mathrm{w}$ analogicznej sytuacji przyjął Stanisław Barańczak, tj. postarać się, by utwór „również w zwykłej lekturze pozostał tym, czym jest w oryginale, to znaczy ładnym, prostym i pozbawionym wszelkiej naciąganej nienaturalności wierszem lirycznym” (Barańczak 2004: 295). Prezentowana strofa jest jednak bodaj najbardziej udaną w całym cyklu (choć i tu zauważamy watę translatorską: „Później” i „swoje”). Bardziej reprezentatywny jest fragment $\mathrm{z}$ Wiosny/Frühling, pierwszego utworu, gdzie banalny poetyzm „krasa” zostaje zrymowany za cenę udziwnienia składni:

\begin{tabular}{|l|l|}
\hline Nun liegst du erschlossen & Teraz leżysz tutaj \\
in Gleiß und Zier, & w swojej pełnej krasie, \\
von Licht übergossen & światło cię opływa \\
wie ein Wunder vor mir. & niczym zjawisko jakieś. \\
\hline
\end{tabular}

Zwłaszcza ostatnia strofa Wiosny budzi wprost zażenowanie (czego z pewnością nie można powiedzieć o oryginale Hessego):

\begin{tabular}{|l|l|}
\hline Du kennst mich wieder, & Poznajesz mnie znowu, \\
du lockest mich zart, & uwodzisz dyskretnie, \\
es zittert durch all meine Glieder & drżą moje członki wobec \\
deine selige Gegenwart. & Twej obecności świętej. \\
\hline
\end{tabular}

Warto przypomnieć, że Jerzy Zagórski stawia przekładom tekstów związanych z muzyką wymóg zestrojenia sensu i wagi słowa $\mathrm{z}$ nastrojem frazy muzycznej (1975: 361). Dlatego takie niezręczności i niestosowności okazują się wyjątkowo niefortunne, gdy reprezentują dzieło będące wielkim pożegnaniem i uchodzące za prawdziwie wspaniałe opus ultimum, jak pisze o nim Aubrey Garlington (1989).

* Cytaty w obu językach za Strauss [2015], choć teksty niemieckie zostały porównane z wydaniami utworów obu poetów, tu np. w celu uzupełnienia uszkodzonego tekstu. 


\section{Aspekty językowe}

Pretensjonalność i niezamierzone dwuznaczności to nie jedyne uchybienia tych przekładów: niewolne są one od zwykłych błędów językowych, często wynikających z nazbyt dosłownego - paradoksalnie, skoro to tłumaczenie poetyckie - odwzorowania sformułowań oryginału. Szczególnie dotkliwe jest nagromadzenie usterek językowych w pieśni O zmierzchu (Im Abendrot Eichendorffa), którą otwiera deklaracja:

Wir sind durch Not und Freude gegangen Hand in Hand.
Chodziliśmy ręka w rękę Poprzez smutki i radości.

„Iść z kimś ręka w rękę" to po polsku „działać zgodnie z kimś; popierać kogoś, współpracować z kimś” (Szymczak 2002); zwrot ten nie konotuje intymności, przyjaźni. Zamiast pierwszego odpowiednika słownikowego lepsze byłoby choćby sformułowanie „z dłonią w dłoni”. W drugiej strofie wszelkiej logice przeczy zwrot „wokół wije się dolina”. U Eichendorffa 'doliny pochylają się - Rings sich die Täler neigen - jest to obraz metaforyczny, może hypallage (w związku z mającym się ku schyłkowi dniem), ale nie językowa aberracja. Trzecia strofa przekładu przynosi transakcentację w klauzuli rymowej: „wkrótce przyjdzie pora snu / [...] w tym osamotnieniu”. Z kolei w końcowej apostrofie do pokoju pierwszy w szeregu przymiotników wskazywałby na to, że mowa o... obszernym pomieszczeniu:

O weiter, stiller Friede!

Pokoju rozległy, błogi,

so tief im Abendrot. Głęboki w wieczornej zorzy!

We względnie udanym przekładzie Września występuje natomiast problem składniowy, wprawdzie nie od razu oczywisty. W oryginale niemieckim podmiotem kolejnych trzech zdań w drugiej połowie utworu jest Sommer, lato („Sommer lächelt..., bleibt er stehn..., tut er die Augen zu” - 'Lato uśmiecha się..., przystaje..., zamyka oczy'). Natomiast w drugiej strofie wersji polskiej „Uśmiech lata odchodzi / razem z marzeniem o ogrodzie”. Podmiotem domyślnym w kolejnych zdaniach jest zatem „uśmiech” - to on stoi przy różach i mruży oczy... Ten osobliwy obraz należy do zgoła innej poetyki.

Problemy językowe wychodzą poza ramy samych utworów. W ulotce koncertowej wszystkie pieśni opatrzone są dedykacjami, lecz nazwiska adresatów pozostają $\mathrm{w}$ trzech przypadkach nieodmienione, wbrew wymogom polszczyzny: 
Pieśn dedykowana biografowi Straussa Willemu Schuh i jego żonie

Pieśń dedykowana sopranistce Marii Jeritza i jej mężowi

Pieśn dedykowana przyjaciołom Straussa, Adolfowi Jöhr i jego żonie.

Jedynie ostatnia pieśń zostaje poświęcona „Ernstowi Rothowi”, którego nazwisko najwyraźniej łatwiej poddało się odmianie. Wobec niegramatyczności sama pieczołowitość w przytaczaniu takiego paratekstu wydaje się jałowa.

\section{Aspekty meliczne}

Naddanie formy poetyckiej (zwłaszcza kosztem uchybień językowych i stylistycznych) nie ma sensu z punktu widzenia potrzeb odbiorcy, jakim jest słuchacz. Tym, co mogłoby uzasadnić takie posunięcie, byłoby przeznaczenie tej wersji - np. pierwotnie - dla wykonawcy. Jednak już zapoznanie się z tłumaczeniem pierwszej z pieśni przekonuje, że tekst nie jest przeznaczony do śpiewania: długość wersów i rozmieszczenie akcentów są zbieżne w zbyt małym stopniu. Można by mówić o odpowiedniości, gdyby rozpatrywać poniższy dwuwiersz jako wiersz toniczny, ale nie, jeśli za jednostkę tłumaczenia przyjmiemy takt (por. Bednarczyk 1993: 139) czy frazę muzyczną:

In dämmrigen Grüften träumte ich lang
W grobowcach mrocznych śniłem bez końca.

Nie tylko rysunek rytmiczny sprawia, że tekst nie nadaje się do wykonania: wersowi „Wie ein Wunder vor mir” (por. w nagraniach: Strauss 1984: nr 1, 1'30), odpowiada wers „niczym zjawisko jakieš", tzn. w miejscu, gdzie pojawia się trudne wykonawczo górne $h$ (por. Baker 2015: 49), tłumaczka umieściła samogłoskę przymkniętą przednią, która może tu zabrzmieć komicznie (por. Zagórski 1975: 359).

Obserwujemy także naruszenie spójności tekstu werbalnego i warstwy muzycznej. Otóż w Im Abendrot mowa o tym, że w niebo ulatują dwa skowronki, zwei Lerchen, i jest to zarazem programowy motyw wpisany w partię fletów piccolo (por. w nagraniach: Strauss 1984: nr 4, 3’50") - bardzo ważny, powracający bowiem w zakończeniu utworu, jako kontrapunkt do ostatnich słów, tj. pytania o śmierć (Krause 1983: 466). W przekładzie „Jeszcze tylko dwie ptaszyny / wznoszą się w wonnym powietrzu". Nastąpiło niefortunne uogólnienie, motywowane rymem do wspomnianej już „doliny”. Co dziwne, tłumaczka przeniosła ten motyw z ostatniej pieśni do pierwszej: tam Vogel- 
sang (śpiew ptaków) staje się „głosem skowronka”. W przekładzie cyklu lirycznego w poezji taki zabieg mógłby okazać się udaną kompensacją. W tym wypadku wszakże skowronek „przefrunął” $\mathrm{z}$ wiersza Eichendorffa do wiersza Hessego i z miejsca w partyturze o charakterze programowym do takiego, gdzie podobnych zabiegów ilustracyjnych kompozytor nie zastosował. Zatem również jako oferta informacji o zestrojeniu sensów słownych z muzycznymi przekład zawodzi odbiorców.

\section{Aspekty intertekstualne}

W rozpatrywanym cyklu, ściślej w Im Abendrot, mamy też do czynienia z cytacyjnością, przy czym na kilku poziomach. Po pierwsze z autonawiązaniem muzycznym - w partii rogu pojawia się reminiscencja z poematu symfonicznego Śmierć $i$ wyzwolenie (Tod und Verklärung), tzw. motyw wyzwolenia, który Strauss kilkukrotnie cytował w późniejszych dziełach (Krause 1983: 233), ale tu tłumacz nie ma nic do roboty. Natomiast tekst werbalny Eichendorffa zawiera wyraźne odwołanie intratekstowe między tytułem a drugim wersem ostatniej strofy: So tief im Abendrot. W przekładzie to echo nie zostało odtworzone - utwór zatytułowany jest $O z m i e r z c h u$, w czwartej strofie mowa jednak o „wieczornej zorzy” (tym zresztą jest Abendrot). Owszem, w strofie drugiej „niebo zatapia się w zmierzchu” (w miejsce „es dunkelt schon die Luft”), jednak nie mamy do czynienia $\mathrm{z}$ dokładnym powtórzeniem - notabene umieszczenie tytułowego okolicznika w ostatniej strofie i semantyczny rym z der Tod, śmiercią, ma w oryginale dużo większą wagę niż kompensacyjne użycie w pierwszej części utworu w przekładzie.

Bartnikowska natomiast intertekstualizuje tekst w odmienny sposób, gdyż podmiot i adresat liryczny kończą „wędrówkę / tu, w krainie łagodności”. Odesłanie do zupełnie innego nurtu muzycznego to zaskakujący adres intertekstualny, który dezorientuje (lub rozbawia) odbiorców na początku refleksyjnego w zamierzeniu utworu.

Summa summarum, w przekładzie cyklu obserwujemy naddanie wartości zbędnych z perspektywy słuchacza, przy czym w sposób kompletnie chybiony. Doszło do drastycznego rozejścia się Translationsskopos obranego przez tłumaczkę i Translatskopos - funkcji, jaką translat pełni w kulturze docelowej (Vermeer 1986). Jakiekolwiek były cele Bartnikowskiej, czterokrotne umieszczenie swojego nazwiska pod tekstami świadczy o zadowoleniu z rezultatów. Natomiast o skopos translatu trudno w ogóle mówić, nie przynosi on bowiem pożytku na żadnym poziomie odbioru. Mimo że przekład nie został 
dostosowany do wymogów meliczności, co rodziłoby dodatkowe niebezpieczeństwa stylistyczne, lecz zarazem może częściowo je rozgrzeszało, tłumaczce nie udało się stworzyć tekstu, który by „przeczytany bez udziału muzyki, nie budził grozy, politowania, ani pustego śmiechu” (Barańczak 2004: 296). Polskiemu odbiorcy tak przełożonych liryków niełatwo będzie uwierzyć, że obcuje z dziełem, które ukazuje charakterystyczny dla pieśni Straussa „prymat idei poetyckiej i podporządkowanie muzyki tekstowi” (Chylińska, Haraschin, Schaeffer 1991: 906). Przekład świadczy o niezrozumieniu zadania translatorskiego i potrzeb odbiorców. W Łodzi wzbudził konsternację niektórych słuchaczy, bynajmniej niebędących filologami. Oznacza to, że naruszona została spójność intratekstualna - między tłumaczeniem a sytuacją odbioru (por. Vermeer 1986). O koherencji intertekstualnej (Vermeer 1986, 1989/2000: 223) tym bardziej nie ma mowy przy pseudopoetyckiej reprezentacji znaczącej poezji.

Skoro FŁ zasadniczo dość chętnie posługuje się gotowymi tekstami (Biblia Tysiąclecia, przekład Piechala), czasem wręcz nie przyznając się do tego, należy postawić pytanie, dlaczego nie postąpiono tak w tym wypadku. Odpowiedź jest nieco zaskakująca: mimo podjętych przeze mnie dość szerokich poszukiwań $\mathrm{w}$ wydaniach monograficznych oraz $\mathrm{w}$ antologiach poetyckich, nie udało mi się odnaleźć tłumaczenia żadnego z trzech utworów Hessego. Niepodobna dociec, czy w FŁ przeprowadzono podobną kwerendę bibliograficzną i na tej podstawie podjęto decyzję, czy też po prostu skorzystano np. z nadesłanego tekstu. Warto jednak nadmienić, że istnieje przynajmniej przekład liryku Eichendorffa - dostępny w druku (m.in. Eichendorff 2004), ale także w Internecie w tzw. Kolekcji niemieckiej poezji klasycznej w przekładach Andrzeja Lama (Eichendorff 2005-2016). Zlokalizowanie tego tekstu nie przedstawia więc problemu, podobnie jak jego wykorzystanie w bezpłatnej ulotce, Kolekcja jest bowiem udostępniana na zasadach licencji Creative Commons. Porównanie $W$ zorzy wieczornej z oryginałem wykracza poza temat niniejszego artykułu, lecz tekst ten z pewnością lepiej reprezentowałby utwór Eichendorffa.

\section{Wnioski}

Nasuwają się następujące konkluzje. Dla Filharmonii Łódzkiej jako zleceniodawcy liczy się produkt (translat), nie wykonawca - można domniemywać, że wkład pracy tłumacza zostaje zaznaczony tylko wtedy, gdy ten sam się o to upomni. Wprawdzie Lawrence Venuti w swoim studium (1995) nie wspomi- 
na o niewidzialności przekładowców w filharmonii, lecz najwyraźniej może ona rozciągać się i na te instytucje kultury.

Produkt również liczy się o tyle, że przywiązuje się wagę do jego istnienia: tendencja do udostępniania publiczności tekstów w języku rodzimym przeważa. Ewentualne odstępstwa nie wynikają jednak ze strategicznej oceny tego, który tekst wymaga tłumaczenia, a który nie. Najwyraźniej brak także kryteriów oceny dostarczonego czy też odszukanego tłumaczenia i weryfikowania jego funkcjonalności. Inicjator chyba w ogóle nie dostrzega potrzeby takiej oceny: najwyraźniej przed koncertem nikt nie sprawdza jakości ani estetyki tekstu (Bartnikowska) czy choćby poprawności przedruku (Carmina burana). Z przekładów można też wnioskować o niedostatecznym precyzowaniu zamówienia (por. Vermeer [1989]2000: 221, 229).

Brak jednolitej strategii prezentowania przekładów i wyboru ich typu (od czysto filologicznych do wykazujących cechy poetyckie lub meliczne) może świadczyć o trudnościach ze zdefiniowaniem potrzeb właściwego odbiorcy tłumaczeń, jakim jest publiczność. Dlatego warto w tym miejscu sformułować cel przekładu tekstu towarzyszącego oryginalnemu wykonaniu wokalnemu jako podanie treści pojęciowej oryginału w sposób poprawny i idiomatyczny. Podkreślmy za Antonim Liberą, że przekładając tekst meliczny „dla potrzeb lektury - obojętne czy szybkiej, na ekranie, w trakcie śpiewu, czy wolniejszej, na kartach programu - powinno się mieć na uwadze przede wszystkim przejrzystość, a nadto formę i styl" danego utworu lub autora (Libera, Borkowska-Rychlewska 2015: 8).

\section{Literatura}

Baker, David J., 2015, [Review of:] „R. Strauss: Vier Letzte Lieder; Ein Heldenleben, Netrebko; Staatskapelle Berlin, Barenboim. Deutsche Grammophon DG 479 3964”, „Opera News”, March 2015, vol. 79, nr 9, s. 49-50.

Barańczak, S., 2004, Ocalone w tłumaczeniu, Kraków, wyd. 3.

Bednarczyk, A., 1993, „Przekład poezji śpiewanej a odtworzenie w nim warstwy muzycznej oryginału", [w:] Literatura $i$ słowo wczoraj $i \mathrm{dziś.} \mathrm{Pi-}$ śmiennictwo rosyjskie a państwo totalitarne, A. Semczuk, W. Zmarzer (red.), Warszawa, s. 135-141.

Carmina burana. Cantiones profanae, 1988, wybór i układ: C. Orff, wstęp i spolszczenie: M. Piechal, Szczecin.

Carmina, b.d., Carl Orff - Carmina Burana [sic] (tłumaczenie), tłum. M. Piechal, micha.waw.pl/carmina.html (dostęp: 1 lipca 2016 r.). 
Chylińska, T., Haraschin, S., Schaeffer, B., 1991, Przewodnik koncertowy, Kraków.

Darlington, A. S. Jr, „Richard Strauss's Vier letzte Lieder: The Ultimate 'opus ultimum”, ,The Musical Quarterly”, vol. 73, nr 1 (1989), s. 79-93.

Eichendorff, J. von, 2004, „W zorzy wieczornej”, [w:] tegoż, Wiosna i miłość.

Poezje, tłum. i oprac. A. Lam, Warszawa, s. 167.

Eichendorff, J. von, 2005-2016, W zorzy wieczornej, [na:] Kolekcja niemieckiej

poezji klasycznej w przekładach Andrzeja Lama, Pułtusk, Akademia Hu-

manistyczna im. A. Gieysztora w Pułtusku, http://www.knpk.ah.edu.pl/

palio/html.run?_Instance $=$ wsh-postgres\&_PageID $=1 \&$ \&CatID $=1403 \&$ _

LangID=1\&_CheckSum=883222741 (dostęp: 2 kwietnia 2016 r.).

FŁ, 2012/2013a, „Kwarta” sez. 2012/2013 nr 1-2 (wrzesień-październik 2012),

czasopismo koncertowe Filharmonii Łódzkiej im. Artura Rubinsteina.

FE, 2012/2013b, „Kwarta” sez. 2012/2013 nr 3-4 (listopad-grudzień 2012).

FŁ, 2012/2013c, „Kwarta” sez. 2012/2013 nr 7-8 (marzec-kwiecień 2013).

FŁ, 2013/2014a, Koncert symfoniczny, 31 stycznia 2014, P. Czajkowski, Ham-

let; D. Szostakowicz, Hamlet, program koncertowy Filharmonii Łódzkiej

im. Artura Rubinsteina.

FŁ, 2013/2014b, „Pójdź ze mną, w dłoni dłoń”. Najpiękniejsze serenady mi-

łosne, 11 lutego 2014, [w:] Program koncertów kameralnych, sezon artystyczny 2013/2014, Filharmonia Łódzka im. Artura Rubinsteina.

FŁ, 2013/2014c, Koncert symfoniczny, 14 lutego 2014, [...] C. Orff, Kantata sceniczna Carmina Burana [sic], program koncertowy.

FŁ, 2013/2014d, Pasyjny koncert symfoniczny, 16 kwietnia 2014, J.S. Bach, Pasja wg św. Jana, program koncertowy.

FŁ, 2014/2015a, Koncert jubileuszowy „100 lat Orkiestry Symfonicznej Filharmonii Łódzkiej”, 13.02.2015, J. Haydn, oratorium Stworzenie świata, program koncertowy.

FŁ, 2014/2015b, Koncert pasyjny, 27.03.2015, J.S. Bach, Pasja według św. Mateusza, program koncertowy.

FŁ, 2014/2015c, Koncert symfoniczny, 15.05.2015, [...] S. Prokofiew, Kantata Aleksander Newski, program koncertowy.

FŁ, 2015/2016a, Koncert symfoniczny, 23.10.2015, F. Mendessohn-Bartholdy, oratorium Eliasz, program koncertowy.

FŁ, 2015/2016b, Koncert symfoniczny, 11.12.2015, [...] R. Strauss, Cztery ostatnie pieśni; program koncertowy.

FŁ, 2015/2016c, Bożonarodzeniowy koncert symfoniczny, 18.12 .2014 [właśc.: 2015], [... C. C. Saint-Saëns, Oratorium na Boże Narodzenie (Oratorio de Noël) op. 12, program koncertowy. 
FŁ, 2015/2016d, Koncert symfoniczny (koncert pożegnalny Kaia Bumanna), 18 marca 2016, J.S. Bach, Msza h-moll, program koncertowy [+ dodatek $\mathrm{z}$ tekstem].

FŁ, 2015/2016e, Koncert pasyjny Media vita in morte sumus (Pośrodku żywota w śmierci jesteśmy), 22 marca 2016, program koncertowy [+ dodatek $\mathrm{z}$ tekstem, oprac. R. Pożarski].

FŁ, 2015/2016f, Koncert oratoryjny na zakończenie sezonu artystycznego 2015/2016, 17 czerwca 2016, C. Orff, Carmina burana, program koncertowy [+ dodatek z tekstem].

Gall, J., 1892, Dziewczę z buzia jak malina, słowa H. Heine, tłum. M. Gawalewicz, Warszawa.

Krause, E., 1983, Ryszard Strauss. Człowiek i dzieło, tłum. K. Bula, Kraków.

Libera, A., Borkowska-Rychlewska, A., 2015, „Zamiast wstępu. »Myśl goni myśl, myśl goni myśl...«. O przekładzie libretta rozmawiają Alina Borkowska-Rychlewska i Antoni Libera", [w:] Libretto i przekład, E. Nowicka, A. Borkowska-Rychlewska (red.), Poznań, s. 5-21.

Marek, T., oprac., 1953, Wybór pieśni kompozytorów polskich, zesz. III, Kraków.

Nord, C., 2009, „Wprowadzenie do tłumaczenia funkcjonalnego. Na przykładzie tytułów i nagłówków", tłum. K. Jaśtal, [w:] Wspótczesne teorie przekładu. Antologia, M. Heydel, P. Bukowski (red.), Kraków, s. 175-192.

Paprocki, W., 2012, „Concerto - eksportowy przebój włoskiego baroku”, „Kwarta” sez. 2012/2013 nr 3-4, s. 39-42.

Paprocki, W., 2013, „Inspiracja z przeszłości”, „Kwarta” sez. 2012/2013 nr 7-8, s. 66-68.

Reiss, K., 1971/2000, „Type, kind and individuality of text. Decision making in translation", tłum. S. Kitron, [w:] The Translation Studies Reader, L. Venuti (red.), London-New York, s. 160-171.

Schäffner, C., 1998 „Skopos theory”, [w:] Routledge Encyclopedia of Translation Studies, M. Baker (red.), London-New York, s. 235-238.

Shaw, B., 1890/1932, Music in London 1890-94, in three volumes, vol. 1, London.

Strauss, R., [2015], Vier letzte Lieder op. posth. (1948) / Cztery ostatnie pieśni na sopran i orkiestrę op. posth., słowa H. Hesse, J. von Eichendorff, tłum. M. Bartnikowska.

Susam-Sarajeva, Ş, 2008, „Translation and Music. Changing Perspectives, Frameworks and Significance”, „The Translator” vol. 14, nr 2, s. 187-200.

Szymczak, M., (red.), 2002, Słownik języka polskiego, Warszawa.

Todd, R. L., b.d., „Mendelssohn, Felix”, [w:] Grove Music Online. Oxford Mu- 
sic Online, D. Root (red.), Oxford University Press, <http://www.oxfordmusiconline.com.grove.han.buw.uw.edu.pl/subscriber/article/grove/ music/51795pg11> (dostęp: 1 lipca 2016 r.).

Venuti, L., 1995, Translator's Invisibility. A History of Translation, London-New York.

Vermeer, H.J., 1986, „Übersetzen als kultureller Transfer”, [w:] Übersetzungswissenschaft - Eine Neuorientierung, M. Snell-Hornby (red.), Tübingen, s. 30-53.

Vermeer, H.J., 1989/2000, „Skopos and commission in translational action”, tłum. A. Chesterman, [w:] The Translation Studies Reader, L. Venuti (red.), London-New York, s. 221-232.

Zagórski, J., 1975, „Tłumaczenie tekstów do muzyki”, [w:] Przekład artystyczny. O sztuce tłumaczenia, Ksiegga druga, S. Pollak (red.), Wrocław, s. 353-366.

\section{Dyskografia}

Strauss, R., 1984, „Vier letzte Lieder”, [na:] tegoż, Lieder, wyk. Jessye Norman, sopran; Gerhard Bosse, skprzypce; Gewandhausorchester Leipzig; dyr. Kurt Masur. Berlin. Pł. gmf.

\section{Translator and skopos in a concert hall \\ Summary}

The subject of the article is the presence of translation in a concert hall, based on the example of activities in the Arthur Rubinstein Philharmonic Orchestra of Lodz in the 2013/14-2015/16 seasons. The author surveys what material is translated, in what ways it is done, and whether the translators are visible. A particular case is discussed, that of a (pseudo)poetic Polish rendition of Richard Strauss' Vier letzte Lieder (texts by Herman Hesse and Joseph von Eichendorff) presented in 2015. This text is examined for aesthetic, linguistic and melic qualities. The aim of the analysis is to verify the functionality of the translations with respect to their recipients (texts made available to concert audiences) - hence the employment of the skopos paradigm in the analysis.

Keywords: translation, music, philharmonic, translation functionality, translator's visibility, Richard Strauss

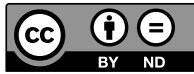

